\title{
ANALISIS PERAN PENINGKATAN PEMBAYARAN NONTUNAI DALAM MEMENGARUHI PERTUMBUHAN EKONOMI
}

\author{
Abdul Azis, Mahyus Ekananda \\ Fakultas Ekonomi dan Bisnis, Universitas Indonesia (UI) Jakarta, Indonesia \\ Email: abdazs.ui@gmail.com,m.ekananda@gmail.com
}

\begin{abstract}
Abstrak
Adanya pergeseran dalam pola sistem pembayaran yang beralih dari pembayaran tunai menuju kepada pembayaran nontunai, menyebabkan bank Indonesia sebagai otoritas harus lebih cermat dalam mengendalikan jumlah uang beredar yang terjadi di masyarakat. Penelitian ini mengkaji pengaruh peningkatan pembayaran nontunai dalam mempengaruhi pertumbuhan ekonomi di Indonesia dengan menggunakan data bulanan pada periode 2009-2019. Penelitian ini didasarkan pada teori netralitas uang yang mengatakan bahwa peningkatan jumlah uang yang beredar hanya berpengaruh kepada variabel nominal namun tidak untuk variabel rill. Dalam melakukan pengujian hipotesis dalam penelitian ini, digunakan estimasai menggunakan metode Vektor Error Correction Model (VECM). Dalam hasil estimasi yang diperoleh, alat pembayaran nontunai dalam periode penelitian yang digunakan dengan proksi data alat pembayaran nontunai berupa nilai transaksi Bank Indonesia Real Time Gross Settlement, nilai dan volume transaksi kartu ATM/Debit, nilai dan volume transaksi kartu kredit, nilai transaksi uang elektronik, nilai transaksi cek dan nilai transaksi giro bepengaruh positif dan signifikan dalam mempengaruhi pertumbuhan ekonomi. Pengaruh pembayaran nontunai yang ditimbulkan dalam mempengaruhi pertumbuhan ekonomi berlaku dalam jangka panjang, sedangkan jangka pendek hanya beberapa alat pembayaran nontunai yang memiliki pengaruh dalam pertumbuhan ekonomi.
\end{abstract}

Kata Kunci: pembayaran nontunai; pertumbuhan ekonomi; permintaan uang

\section{Abstract}

The shifting of payment system method from cash payment to noncash payment causes the Bank Central (Bank Indonesia) to be more prudent in controlling the Amount of money spent in the community. The study aims to examine the effect of the increasing of cashless payment that affect the indonesian economic growth using monthly data for 2009-2019 period. This research is based on the theory of money neutrality which says that the increasing of the amount of money spent in community only affect the nominal variable but not the real variable. In testing the hypothesis in this study, performed using Vector Error Correction Model (VECM). The estimation result shows that noncash payment in the study period were used with data proxy non-cash payment instrument in the form of transaction value Bank Indonesia real time gross settlement, value and volume of ATM/Debit Card transaction. Value and volume of credit card, value and volume of electronic 
money, transaction value of check and transaction value of giro have a positive and significant influence in the the economic growth. The effect of non-cash payment that are arising in influencing the economic growth applies in the long term, whereas in the short term there is only few noncash instrumen that have influence on economic growth.

Keywords: noncash payment; economic growth; money demand

Received: 2021-11-20; Accepted: 2021-12-05; Published: 2021-12-20

\section{Pendahuluan}

Teknologi yang terus berkembang semakin pesat membuat transformasi sistem pembayaran juga semakin berkembang, khususnya perkembangan pada sistem pembayaran nontunai. (Bank Indonesia, 2011) mendefinisikan sistem pembayaran sebagai suatu suatu sistem yang mencakup seperangkat aturan, lembaga, dan mekanisme yang digunakan untuk melaksanakan pemindahan dana untuk memenuhi suatu kewajiban yang timbul dari suatu kegiatan ekonomi yang dilakukan. Dalam (Mulyati \& Ascarya, 2003) dikatakan bahwa sistem pembayaran merupakan suatu kesatuan dengan sistem keuangan serta perbankan yang tidak dapat dipisahkan. Sistem pembayaran yang berhasil tentunya akan menunjang terjadi perkembangan pada sistem keuangan dan perbankan yang ada. Kegagalan yang juga mungkin terjadi pada sistem pembayaran juga pasti akan memberikan dampak negatif yang dapat menghambat perkembangan sistem keuangan dan perbankan yang akhirnya akan mempengaruhi kestabilan ekonomi secara menyeluruh.

Di semua negara tidak terkecuali di Indonesia, perkembangan teknologi yang semakin pesat juga mendorong adanya perubahan pada pola pembayaran untuk setiap transaksi didalam kegiatan ekonomi. (Pramono et al., 2006) mengatakan bahwa kemajuan teknologi yang terjadi pada sistem pembayaran saat ini memberikan dampak pada pergeseran peran uang tunai (Currency) sebagai alat pembayaran pada kegiatan ekonomi. Pergeseran tersebut akan mengarah kepada alat pembayaran nontunai yang dinilai lebih ekonomis dan efisien ketika digunakan oleh masyarakat.

Berdasarkan penelitian yang dilakukan oleh (Aristiyowati \& Falianty, 2019) mengenai inovasi pada sistem pembayaran dan pengaruhnya pada permintaan currency, M1 dan M2 di Indonesia dijelaskan bahwa inovasi finasial pada sistem pembayaran berpengaruh negatif terhadap currency dan M1. Hal tersebut berimplikasi bahwa terjadinya perkembangan pada sistem pembayaran akan menggeser peran uang tunai dalam melakukan transaksi. Pembayaran nontunai dalam setiap transaksi tidak lagi menggunakan uang tunai sebagai alat pembayarannya, tetapi dengan metode pembayaran berupa transfer yang dilakukan melalui lembaga keuangan maupun menggunakan instrumen alat pembayaran non-tunai lainnya.

Secara umum di Indonesia perkembangan sistem pembayaran sedang dan terus mengarah kepada sistem pembayaran non-tunai (Hidayat et al., 2006). Perkembangan yang pesat pada sistem pembayaran nontunai menjadi pendukung pada kegiatan 
ekonomi. Di Indonesia, dalam lima tahun terakhir berdasarkan data yang tercatat pada Statistik Ekonomi dan Keuangan Indonesia (SEKI) Bank Indonesia memang terjadi peningkatan pada berbagai instrument pembayaran nontunai. Pada penyelesaian transaksi yang menggunakan sistem Bank Indonesia Real Time Gross Settlement (BIRTGS) dari tahun 2009 hingga 2019 mengalami peningkatan masing-masing sebesar $25 \%$ dan $310 \%$ unutuk volume dan nilai transaksi. Hal tersebut terjadi karena semakin luasnya cakupan pada peng-implementasian sistem pembayaran non-tunai melalui BIRTGS. Peningkatan pada alat pembayaran menggunakan kartu berupa kartu ATM/Debit pada periode 2009 hingga 2019 masing-masing sebesar 424\% dan 312\% untuk volume dan nilai transaksi, serta kartu kredit pada periode yang sama masing-masing sebesar $128 \%$ dan $238 \%$ pada volume dan nilai transaksi kartu kredit. Peningkatan yang signifikan juga terjadi pada alat pembayaran nontunai berupa uang elektronik masingmasing sebesar $10.441 \%$ dan 78.254 sejak 2009 hingga 2019 untuk volume dan nilai transaksi.

Dengan semakin mudahnya kegiatan bayar membayar dalam transaksi membuat masyarakat dapat melakukan kegiatan tersebut dengan cepat dan efisien. Akibatnya perputaran dalam ekonomi yang terjadi akan menjadi semakin cepat. Dalam (Warjiyo \& Solikin, 2003) dikatakan bahwa sistem pembayaran nontunai akan memiliki peran yang semakin vital dan besar dalam sistem perkonomian, karena selain ber-manfaat bagi masyarakat sebagai pengguna dan objek yang dilayani secara langsung, sistem pembayaran nontunai juga memiliki pengaruh pada sistem keuangan nasional secara keseluruhan.

Kehadiran berbagai alat pembayaran nontunai menurut (Pramono et al., 2006) bukan hanya semata karena inovasi dari aktivitas usaha perbankan, melainkan adanya kebutuhan yang muncul dari masyarakat sebagai pengguna insturmen pembayaran yang dapat memberikan manfaat kepada masyarakat berupa kemudahan untuk melakukan transaksi dalam kegiatan ekonomi. Dalam (Igamo \& Falianty, 2018) atas penelitiannya mengenai pembayaran nontunai dengan proksi electronic money ditunjukan bahwa adanya efisiensi sistem pembayaran yang di-sebabkan atas penggunaan uang elektronik, menyebabkan terjadinya peningkatan pada tingkat konsumsi masyarakat.

(Dias, 2001) mengatakan bahwa adanya kemudahan yang diberikan atas penggunaan alat pembayaran nontunai nantinya akan mendorong terjadinya penurunan biaya transaksi. Penurunan biaya transaksi yang terjadi akan mendorong terjadinya peningkatan pada tingkat konsumsi, permintaan barang, dan atau jasa serta selanjutnya akan menstimulus kegiatan ekonomi pada sektor rill dan pada gilirannya mendorong terjadinya pertumbuhan di-dalam perekonomian. Alat pembayaran nontunai, khususnya alat pembayaran menggunakan kartu memiliki dampak yang sangat berarti terhadap ekonomi dunia. Berdasarkan Moody's Analytics yang dipublikasikan oleh Visa Inc, dijelaskan bahwa penggunaan alat pembayaran meng-gunakan kartu yang semakin besar dalam bertransaksi meningkatkan tingkat kon-sumsi rata-rata pada 56 negara sebesar 0.7\% dan tingkat GDP global sebesar 1.8\% dalam periode 2008 hingga 2012 (Zandi et al., 2013). 
Dalam teori moneter klasik dijelaskan adanya perubahan yang terjadi pada penawaran uang akan berpengaruh pada variabel nominal, tetapi tidak menyebabkan perubahan pada variabel rill. Peningkatan pada alat pembayaran nontunai yang semakin pesat perkembangannya saat ini tentu akan memunculkan sebuah per-tanyaan apakah terjadinya peningkatan penawaran pada alat pembayaran nontunai tersebut hanya akan berpengaruh pada variabel nominal saja tanpa memberikan efek pada variabel rill seperti pertumbuhan ekonomi.

Pada (Lucas, 1995), dinyatakan bahwa netralitas uang merupakan sebuah kondisi yang ditunjukan ketika terjadinya pe-rubahan pada tingkat jumlah uang yang beredar dimasyarakat hanya akan me-nimbulkan pengaruh pada variabel nominal di dalam perekonomian seperti tingkat harga, upah nominal maupun tingkat kurs rupiah terhadap mata uang asing, tetapi tidak menyebabkan terjadinya perubahan pada tingkat output, konsumsi, maupun investasi serta kesempatan kerja yang merupakan jenis dari variabel rill.

Sejalan dengan Lucas, Hume yang merupakan seorang ekonom dari aliran klasik juga menyatakan kenaikan pada kuantitas uang beredar tidak akan mem-pengaruhi pertumbuhan pada output maupun investasi yang merupakan variabel rill, namun hanya menyebabkan perubahan pada tingkat harga yaitu inflasi. Pandangan lain yang disampaikan oleh Gurley dan Shaw (1960) di dalam buku yang ditulis oleh (Warjiyo \& Solikin, 2016) dinyatakan bahwa perubahan pada kuantitas uang yang terjadi tidak hanya mendorong terjadinya pe-nurunan maupun kenaikan harga umum, namun juga mempengaruhi harga relatif dan selanjutnya berpengaruh terhadap output didalam perekonomian. Oleh karena itu, penelitian mengenai peningkatan pada alat pembayaran nontunai dalam mem-pengaruhi pertumbuhan ekonomi sangat pent penting untuk dilakukan, mengingat peran bank sentral dalam menetapkan kebijakan moneter.

Dalam penelitian yang dilakukan beberapa tahun terakhir telah digunakan beberapa proksi data yang digunakan untuk mengukur alat pembayaran nontunai dalam mempengaruhi perekonomian. Beberapa peneliti yang menggunakan proksi Alat Pembayaran Menggunakan Kartu (APMK) berupa kartu ATM/Debit dan atau kartu kredit yaitu (Moelgini et al., 2019), (Nirmala \& Widodo, 2011), (Pramono et al., 2006), (Oyewole et al., 2013) dan (Cassoni \& Ramada, 2013). Penelitian (Tee \& Ong, 2016) mulai mengakomodir alat pembayaran nontunai lainnya berupa telegraphic transfer dan electronic money dalam menganalisis cashless payment dan economic growth. Penelitian (Syarifuddin et al., 2009) juga telah mengakomodir BI-RTGS sebagai salah satu proksi alat pembayaran nontunainya dalam penelitian mengenai pengaruh pembayaran nontunai terhadap perekonomian dan implikasinya terhadap pengendalian moneter.

Dari beberapa penelitian yang telah dilakukan sebelumnya, proksi yang digunakan dalam alat pembayaran nontunai cukup beragam. Karenanya dalam penelitian mengenai peran peningkatan alat pem-bayaran nontunai yang dilakukan kali ini digunakan proksi data yang lengkap dan komperhensif untuk alat pembayaran nontunai. Adapun proksi alat pembayaran nontunai yang digunakan yaitu: Alat pembayaran 
menggunakan kartu (APMK) berupa kartu ATM/Debit, kartu kredit, BI-RTGS, electronic money, cek serta bilyet giro. Adapaun pertanyaan yang akan dijawab dalam penelitian ini adalah bagaimana pengaruh masing-masing alat pembayaran nontunai (Alat Pembayaran Menggunakan Kartu (APMK), BI-RTGS, Cek, Bilyet giro dan Electronic Money) terhadap per-tumbuhan ekonomi.

Adapun tujuan dalam melakukan penelitian ini yaitu mengidentifikasi pengaruh masing-masing alat pembayaran nontunai pengaruh masing-masing variabel alat pembayaran nontunai (Alat Pembayaran Menggunakan Kartu (APMK), BI-RTGS, Cek, Bilyet giro dan electronic money) terhadap pertumbuhan ekonomi.

\section{Metode Penelitian}

\section{A. Sumber Data}

Data yang digunakan dalam penelitian adalah data alat pembayaran nontunai berupa APMK, BI-RTGS, electronic money, cek dan bilyet giro, data GDP rill, data upah rill, data suku bunga, data nilai tukar, data inflasi dalam periode 2009 hingga 2019. Pertimbangan penggunaan data pada periode tersebut, karena data alat pembayaran nontunai baru tersedia sejak 2009. Sumber data atas data penelitian ini berasal dari data Statistik Ekonomi dan Keuangan Indonesia (SEKI BI) dan Badan Pusat Statistik (BPS) Indonesia. Data penelitian yang bersumber dari Badan Pusat Statistik Indonesia berupa data GDP (dalam miliar rupiah) dan data inflasi (dalam persen). Sedangkan data yang berasal dari SEKI BI berupa data nilai tukar (dalam ribu rupiah), data nilai dan volume transaksi kartu ATM/debit, nilai dan volume transaksi kartu kredit, nilai transaksi cek, nilai transaksi giro (dalam juta rupiah).

\section{B. Definisi Operasional Variabel}

Variabel dependen yang digunakan dalam penelitian ini yaitu variable Gross Domestic Product (GDP) dalam periode 2009 hingga 2019 dalam miliar rupiah. Sedangkan variable independennya adalah variable alat pembayaran nontunai yang meliputi APMK berupa kartu debit dan kartu kredit, BI-RTGS, electronic money, cek dan bilyet giro.

\section{Model Empiris}

Penelitian mengenai analisis peningkatan pembayaran nontunai dalam mempengaruhi pertumbuhan ekonomi di Indonesia merujuk pada penelitian yang dilakukan oleh (Aristiyowati \& Falianty, 2019); (Pramono et al., 2006); (Tee \& Ong, 2016) dengan beberapa penyesuaian pada beberapa variabel yang digunakan dalam penelitian. Adapaun spesifikasi model VECM yang digunakan dituliskan sebagai berikut:

$$
\Delta Y_{t}=\rho_{0}+\sum_{i=1}^{n} \Gamma \Delta Y_{t-1}+\gamma_{1} E C T_{t-1}+\varepsilon_{t}
$$

Dimana $\Delta Y_{t}$ merupakan bentuk matriks first difference, sebagai berikut: 


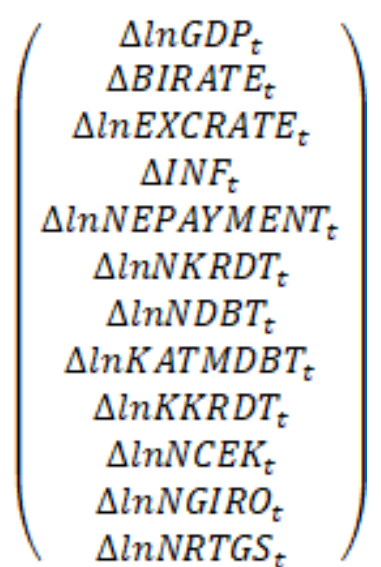

Dengan $\ln G D P_{t}$ adalah Gross Domestik Product pada bulan t, BIRATE adalah suku bunga Bank Indonesia pada bulan $\mathrm{t}, \operatorname{lnEXCRATE_{t}}$ adalah kurs nilai tukar pada bulan $\mathrm{t}, I N F_{t}$ adalah tingkat inflasi pada bulan $\mathrm{t}$, $\operatorname{lnNEPAYMENT}$ adalah nilai transaksi uang elektronik pada bulan $\mathrm{t}, \ln N K R D T_{t}$ adalah pertumbuhan nilai tran-saksi kartu kredit pada bulan t, $\ln N D B T_{t}$ adalah pertumbuhan nilai transaksi kartu debit pada bulan $\mathrm{t}, \ln K A T M D B T_{t}$ adalah kartu ATM/DBT pada bulan t, $\ln K K R D T_{t}$ adalah volume transaksi kartu debet pada bulan $\mathrm{t}, \ln N C E K_{t}$ adalah nilai transaksi cek pada bulan t, $\ln N G I R O_{t}$ adalah nilai transaksi bilyet giro pada bulan t dan $\operatorname{lnNRTGS}_{t}$ adalah nilai transaksi BI-RTGS pada bulan t. $\rho_{0}$ merupakan vektor konstanta untuk masing-masing variable penelitian yang telah di-paparkan sebelumnya. Sedangkan $\sum_{i=1}^{n} \Gamma \Delta Y_{t-1}$ merupakan matriks yang terdiri dari parameter ( $\Gamma)$ dan berupa matriks komponen variabel penelitian dalam bentuk lag dari first difference $\left(\Delta Y_{t-1}\right)$. Adapun matriks $\Gamma$ adalah sebagai berikut:

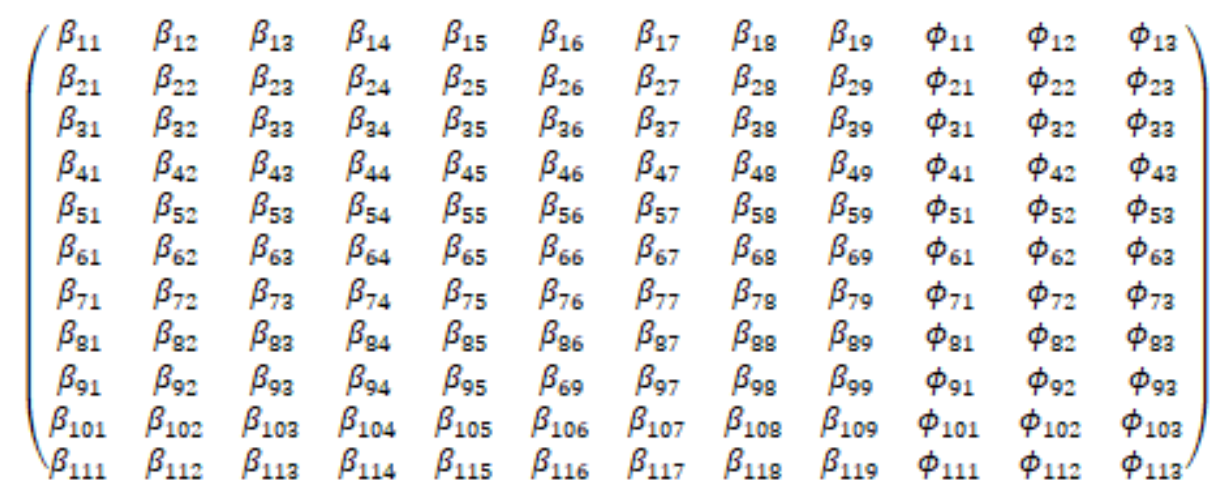

Untuk ECT merupakan error correction term dan $\varepsilon_{t}$ adalah nilai residual. Variabel yang digunakan dalam penelitian seluruhnya diubah kedalam bentuk logaritma natural yaitu $\ln G D P, \ln E X C R A T E, \ln E P A Y M E N T$, InNKRDT, $\ln N D B T$, InKATMDBT, InKKRDT, InNCEK, InNGIRO, InNRTGS. Sedangkan variable dalam satuan persen tidak diubah yaitu BIRATE dan INF. Dalam menjelaskan peningkatan 
pem-bayaran nontunai dalam mempengaruhi pertumbuhan ekonomi, maka hipotesis yang akan diuji dalam penelitian ini adalah se-bagai betikut:

1. Peningkatan dalam pembayaran nontunai meningkatkan pertumbuhan ekonomi.

$$
\sigma_{15} \neq 0, \sigma_{16} \neq 0, \sigma_{17} \neq 0, \sigma_{18} \neq 0, \sigma_{19} \neq 0, \phi_{11} \neq 0, \phi_{12} \neq 0, \phi_{13} \neq 0
$$

Dalam melakukan pembuktian hipotesis yang diajukan, dilakukan langkahlangkah pengujian akar unit pada variabel penelitian untuk menghindari spurious regression, 2) Pemelihan panjang lag optimum yang didasarkan pada kriteria $L R, H Q, S C$ dan $A I C, 3)$ pengujian stabilitas model VAR yang digunakan agar Variance Decomposition yang dihasilkan valid, 4) pengujian ada tidaknya kointegrasi pada variabel penelitian untuk melihat ada tidaknya hubungan jangka panjang antar variabel, sehingga dapat diputuskan estimasi menggunakan VECM dapat dilanjutkan atau cukup hanya menggunakan VAR standar saja, 5) estimasi VECM dengan strategi menggunakan variabel penelitian yang telah dipaparkan, dilanjutkan menggunakan variabel kliring dan breakdown pada periode estimasi penelitian yang dapat digunakan untuk melihat prilaku data penelitian.

\section{Hasil dan Pembahasan}

\section{A. Analisis Pengaruh Peningkatan Pem-bayaran Nontunai terhadap Pertumbuhan Ekonomi.}

Pengujian unit root test menggunakan metode Augmented Dickey Fuller (ADF) test, dapat disimpulkan bahwa variabel stasioner pada first difference (I(1)), lag optimal pada model yang digunakan berdasarkan kriteria nilai AIC, SC, HQ dan LR adalah pada lag 1. Sehingga lag yang digunakan dalam estimasi model penelitian ini adalah lag 1. Pengujian kointegrasi dengan menggunakan metode Johansen System Cointegration Test, terdapat tiga kointegrasi yang menunjukan bahwa terdapat hubungan jangka Panjang antara variabel $\ln G D P$ sebagai variabel dependen dengan variabel independennya. Pengujian stabilitas model dengan menggunakan pengujian roots of characteristic polynomial, diperoleh hasil bahwa model yang digunakan dalam penelitian adalah stabil dimana nilai modulus dari roots of characteristic polynomial lebih kecil dari satu. 


\section{VECM dengan Menggunakan Nilai Transaksi Kliring}

Hasil estimasi VECM dengan menggunakan nilai transaksi kliring adalah sebagai berikut:

Tabel 1

Hubungan Antara Alat Pembayaran Nontunai Dengan Proksi Nilai Transaksi Kliring Dengan Pertumbuhan Ekonomi

\begin{tabular}{|c|c|c|c|}
\hline Cointegrating Equation : & CointEq1 & CointEq2 & CointEq3 \\
\hline $\ln$ GDP(-1) & 1.000 & 0.000 & 0.000 \\
\hline $\ln$ EXCRATE(-1) & 0.000 & 1.000 & 0.000 \\
\hline BIRATE(-1) & 0.000 & 0.000 & 1.000 \\
\hline \multirow[t]{2}{*}{ INF(-1) } & 1.031 & 8.251 & 1.394 \\
\hline & {$[2.589]^{* *}$} & {$[3.207]^{* *}$} & {$[3.282]^{* *}$} \\
\hline \multirow[t]{2}{*}{$\ln$ KATMDBT(-1) } & -8.525 & -44.732 & -7.159 \\
\hline & {$[-5.318]^{* * *}$} & {$[-4.318] * * *$} & {$[-4.186]^{* * *}$} \\
\hline \multirow[t]{2}{*}{$\ln$ KKRDT(-1) } & -19.072 & -118.063 & -18.561 \\
\hline & {$[-7.773]^{* * *}$} & {$[-7.446]^{* * *}$} & {$[-7.092]^{* * *}$} \\
\hline \multirow[t]{2}{*}{$\ln \mathrm{NDBT}(-1)$} & -0.674 & -10.955 & -2.104 \\
\hline & {$[-0.662]$} & {$[-1.665]^{*}$} & {$[-1.937]^{*}$} \\
\hline \multirow[t]{2}{*}{ lnNEPAYMENT(-1) } & -0.071 & -0.458 & -0.043 \\
\hline & {$[-0.307]$} & {$[-0.306]$} & {$[-0.173]$} \\
\hline \multirow[t]{2}{*}{$\ln$ NKLRG(-1) } & -0.166 & 0.472 & 0.139 \\
\hline & {$[-0.167]$} & {$[0.073]$} & {$[0.131]$} \\
\hline \multirow[t]{2}{*}{$\ln$ NKRDT(-1) } & -25.203 & 154.142 & 24.0127 \\
\hline & {$[8.524]^{* * *}$} & {$[8.067]^{* * *}$} & {$[7.613]^{* * *}$} \\
\hline \multirow[t]{2}{*}{$\ln$ NRTGS(-1) } & -2.880 & 20.379 & 3.274 \\
\hline & {$[4.424]^{* *}$} & {$[4.843]^{* *}$} & {$[4.714]^{* *}$} \\
\hline
\end{tabular}

Sumber : Data Olahan Eviews,

*signifikan pada $\alpha=10 \%$, ** signifikan pada $\alpha=5 \%$, *** signifikan pada $\alpha=1 \%$.

Dalam table 1 di atas, maka persamaan kointegrasi dari hasil estimasi yang diperoleh adalah sebagai berikut:

$$
\begin{aligned}
& E C T_{t-1}=1.000 \ln G D P_{t-1}+1.030{ }^{N} F_{t-1}-8.525 \ln K A T M D B T_{t-1} \\
&-19.072 \ln K K R D T_{t-1}-0.674 \ln N D B T_{t-1} \\
&-0.070 \ln N E P A Y M E N T_{t-1}-0.166 \ln N K L R G_{t-1} \\
&-25.304 \ln N K R D T_{t-1}-2.880 \ln N R T G S_{t-1}
\end{aligned}
$$

Hasil estimasi VECM menunjukkan nilai ECT yang signifikan secara statistik, hal tersebut berimplikasi bahwa hasil estimasi VECM yang dilakukan adalah valid untuk dilakukan analisis. Nilai koefisien atas ECT (-1) pada hasil estimasi VECM yang dilakukan bernilai negatif dan kurang dari satu. Nilai ECT sebesar 0,314 bermakna jika terdapat perbedaan pada nilai aktual GDP dengan keseimbanganya sebesar 0,314, maka akan dikoreksi dan disesuaikan pada setiap periodenya.

Pada tabel 1 yang merupakan persamaan kointegrasi dan estimasi model jangka panjang menunjukkan bahwa adanya hubungan antara sistem 
pembayaran nontunai dengan pertumbuhan ekonomi dengan proksi variabel Gross Domestik Product. Dari estimasi tersebut juga dapat disimpulkan bahwa transaksi pembayaran nontunai dengan proksi nilai transaksi RTGS (NRTGS), volume dari kartu ATM/Debit (KATMDBT), nilai transaksi dari kartu debit (NDBT), volume dari kartu kredit (KKDRT), nilai transaksi dari kartu kredit (NKRDT) memiliki pengaruh positif dan signifikan dalam mempengaruhi pertumbuhan ekonomi. Untuk nilai transaksi melalui sistem pembayaran RTGS, apabila terjadi peningkatan transaksi melalui BI-RTGS sebesar $1 \%$ maka menyebabkan adanya peningkatan GDP sebesar 2,88\% satuan GDP. Begitupun apabila terjadi peningkatan pada kartu debit baik dari segi nilai transaksi maupun volume transaksi maka akan menyebabkan kenaikan pada GDP masingmasing sebesar 0,67\% dan 8,52\% satuan GDP. Sedangkan jika terjadi kenaikan $1 \%$ pada penggunaan alat pembayaran nontunai berupa kartu kredit untuk bertransaksi baik dari segi nilai dan volume transaksi, maka akan berpengaruh pada GDP masing-masing sebesar 25,20\% dan 19,07\% satuan GDP. Sedangkan hasil estimasi untuk model jangka pendek dalam penelitian, dapat disimpulkan bahwa proksi alat pembayaran nontunai kecuali nilai transaksi e-money (NEPAYMENT) tidak berpengaruh signifikan pada tingkat $\alpha=5 \%$ dalam mempengaruhi tingkat GDP.

2. VECM dengan Menggunakan Nilai Transaksi Cek dan Bilyet Giro

Hasil estimasi VECM dengan menggunakan nilai transaksi cek dan bilyet giro adalah sebagai berikut:

Tabel 2

Hubungan Antara Alat Pembayaran Nontunai Dengan Proksi Nilai Transaksi Cek Dan Bilyet Giro Dengan Pertumbuhan Ekonomi

\begin{tabular}{|c|c|c|}
\hline Cointegrating Equation : & CointEq1 & CointEq2 \\
\hline $\ln$ GDP(-1) & 1.000 & 0.000 \\
\hline BIRATE(-1) & 0.000 & 1.000 \\
\hline \multirow[t]{2}{*}{ lnEXCRATE(-1) } & -0.676 & -10.22 \\
\hline & {$[-3.253] * * *$} & {$[-4.573]$} \\
\hline \multirow[t]{2}{*}{ INF(-1) } & 0.130 & 1.273 \\
\hline & {$[3.072]^{* * *}$} & {$[2.805]$} \\
\hline \multirow[t]{2}{*}{$\operatorname{lnKATMDBT(-1)}$} & -1.019 & -8.981 \\
\hline & {$[-4.432] * * *$} & {$[-3.631]$} \\
\hline \multirow[t]{2}{*}{$\operatorname{lnKKRDT(-1)}$} & -0.786 & -8.101 \\
\hline & {$[-1.459]$} & [-1.398] \\
\hline \multirow[t]{2}{*}{$\ln \mathrm{NCEK}(-1)$} & 0.538 & 2.526 \\
\hline & {$[3.225]^{* * *}$} & [ 1.407$]$ \\
\hline \multirow[t]{2}{*}{$\operatorname{lnNDBT}(-1)$} & 0.133 & 2.111 \\
\hline & {$[0.868]$} & {$[1.275]$} \\
\hline \multirow[t]{2}{*}{$\operatorname{lnNEPAYMENT(-1)}$} & -0.064 & -0.364 \\
\hline & {$[-2.690]^{* * *}$} & {$[-1.412]$} \\
\hline \multirow[t]{2}{*}{$\operatorname{lnNGIRO(-1)}$} & -0.463 & -2.433 \\
\hline & {$[-2.231]^{* * *}$} & {$[-1.090]$} \\
\hline \multirow[t]{2}{*}{$\ln$ NKRDT(-1) } & 2.267 & 27.935 \\
\hline & {$[9.139]^{* * *}$} & [ 10.465] \\
\hline
\end{tabular}




\begin{tabular}{lcc}
\hline $\operatorname{lnNRTGS(-1)}$ & 0.185 & 2.291 \\
\hline & {$[2.855]^{* * *}$} & {$[3.282]$} \\
\hline $\mathrm{C}$ & -18.605 & -143.418 \\
\hline
\end{tabular}

Sumber : Data Olahan Eviews,

*signifikan pada $\alpha=10 \%, * *$ signifikan pada $\alpha=5 \%$, *** signifikan pada $\alpha=1 \%$.

Dalam table 2 di atas, maka persamaan kointegrasi dari hasil estimasi yang diperoleh adalah sebagai berikut:

$$
\begin{aligned}
& E C T_{t-1}=1.000 \ln \text { GDP }_{t-1}-0.676 \text { EXCRATE }_{t-1}+0.130 I N F_{t-1} \\
& -1.019 \ln K A T M D B T_{t-1}-0.786 \operatorname{lnKKRDT}_{t-1}+0.538 \ln N C E K_{t-1} \\
& +0.538 \ln N D B T_{t-1}-0.064 \ln N E P A Y M E N T_{t-1}-0.463 \ln N G I R O_{t-1} \\
& +2.267 \ln N K R D T_{t-1}+0.185 \operatorname{lnNRTGS_{t-1}}
\end{aligned}
$$

Hasil estimasi VECM dengan menyertakan variabel alat pembayaran nontunai berupa cek dan bilyet giro menunjukkan nilai ECT yang signifikan secara statistik. Hal tersebut berimplikasi bahwa hasil estimasi VECM yang dilakukan adalah valid untuk dilakukan analisis. Dalam tabel 2, nilai koefisien atas ECT (-1) bernilai negatif dan kurang dari satu. Nilai ECT sebesar 0,367 bermakna jika terdapat perbedaan pada nilai aktual GDP dengan keseimbanganya sebesar 0,367, maka akan dikoreksi dan disesuaikan pada setiap periodenya.

Hasil estimasi VECM untuk model jangka panjang pada tabel 2. ditunjukan bahwa terdapat hubungan pada alat pembayaran nontunai dengan pertumbuhan ekonomi dengan proksi variabel Gross Domestik Product. Dari estimasi tersebut juga dapat disimpulkan bahwa transaksi pem-bayaran nontunai dengan proksi volume kartu ATM/Debit (KATMDBT), nilai transaksi cek (NCEK), nilai transaksi uang elektronik (NEPAYMENT), nilai transaksi giro (NGIRO), nilai transaksi dari kartu kredit (NKRDT) dan nilai transaksi dari RTGS (NRTGS) berpengaruh signifikan dalam mempengaruhi pertumbuhan ekonomi.

Untuk nilai transaksi melalui pembayaran dengan menggunakan kartu debit, apabila terjadai kenaikan $1 \%$ pada nilai maupun volume transaksi yang maka akan berpengaruh terhadap pertumbuhan ekonomi masing-masing sebesar $1.019 \%$ dan $0,133 \%$ satuan GDP. Sedangkan apabila terjadi kenaikan pada transaksi nontunai menggunakan cek sebesar $1 \%$ maka akan berpengaruh pada GDP sebesar $0.538 \%$. Peningkatan yang terjadi pada uang elektronik sebesar $1 \%$, akan menyebabkan peningkatan pada GDP sebesar $0.064 \%$ satuan GDP. Serta kenaikan transaksi dengan menggunakan alat pembayaran nontunai berupa bilyet giro sebesar $1 \%$ juga menyebabkan terjadinya peningkatan pada GDP sebesar $0.463 \%$ satuan GDP. Kenaikan pada nilai transaksi BI-RTGS sebesar $1 \%$, akan berdampak pada pertumbuhan ekonomi sebesar $0.185 \%$ satuan GDP. 
Pada hasil estimasi untuk model jangka pendek dalam penelitian, dapat disimpulkan bahwa proksi alat pembayaran nontunai tidak semuanya berpengaruh secara sig-nifikan dalam mempengaruhi pertumbuhan ekonomi. Hanya variabel volume transaksi menggunakan kartu ATM/Debit, nilai transaksi menggunakan cek, nilai transaksi menggunakan giro dan nilai transaksi dari kartu kredit yang berpengaruh positif dan signifikan terhadap pertumbuhan ekonomi.

\section{Analisis Variance Decomposition Alat Pem-Bayaran Nontunai Terhadap Pertumbuhan Ekonomi}

Analisis variance decomposition dalam penelitian ini digunakan untuk melihat pengaruh shock yang terjadi pada berbagai alat pembayaran nontunai dalam mempengaruhi pertumbuhan ekonomi.

\section{Tabel 3}

Variance Decomposition Of GDP Menggunakan Kliring

\begin{tabular}{cccccccccc}
\hline $\begin{array}{c}\text { Period } \\
\mathbf{e}\end{array}$ & S.E. & GDP & $\begin{array}{c}\text { KATMDB } \\
\mathbf{T}\end{array}$ & $\begin{array}{c}\text { KKRD } \\
\mathbf{T}\end{array}$ & $\begin{array}{c}\text { NDB } \\
\mathbf{T}\end{array}$ & $\begin{array}{c}\text { NEPAYMEN } \\
\mathbf{T}\end{array}$ & $\begin{array}{c}\text { NKLR } \\
\text { G }\end{array}$ & $\begin{array}{c}\text { NKRD } \\
\mathbf{T}\end{array}$ & $\begin{array}{c}\text { NRTG } \\
\text { S }\end{array}$ \\
\hline $\mathbf{1}$ & 0,068 & 100,000 & 0,000 & 0,000 & 0,000 & 0,000 & 0,000 & 0,000 & 0,000 \\
$\mathbf{2}$ & 0,119 & 97,353 & 0,068 & 0,043 & 0,042 & 1,289 & 0,421 & 0,001 & 0,150 \\
$\mathbf{5}$ & 0,207 & 89,209 & 0,722 & 0,065 & 0,027 & 3,655 & 0,616 & 0,558 & 0,464 \\
$\mathbf{1 0}$ & 0,257 & 77,708 & 4,590 & 0,487 & 0,064 & 3,956 & 0,989 & 0,730 & 1,010 \\
$\mathbf{1 5}$ & 0,286 & 66,647 & 10,269 & 1,473 & 0,069 & 3,260 & 1,350 & 0,667 & 1,544 \\
$\mathbf{2 0}$ & 0,312 & 57,252 & 15,298 & 2,478 & 0,065 & 2,769 & 1,625 & 0,807 & 1,954 \\
$\mathbf{2 5}$ & 0,337 & 49,956 & 19,223 & 3,299 & 0,061 & 2,443 & 1,827 & 0,986 & 2,257 \\
$\mathbf{3 0}$ & 0,360 & 44,332 & 22,251 & 3,943 & 0,057 & 2,210 & 1,980 & 1,145 & 2,486 \\
$\mathbf{3 5}$ & 0,382 & 39,917 & 24,628 & 4,451 & 0,053 & 2,031 & 2,099 & 1,276 & 2,665 \\
$\mathbf{3 6}$ & 0,386 & 39,148 & 25,043 & 4,540 & 0,053 & 2,001 & 2,119 & 1,300 & 2,696 \\
\hline
\end{tabular}

\section{Sumber : Data Olahan Eviews}

Dalam tabel 3 yang merupakan hasil variance decomposition dari model yang digunakan dalam penelitian ini terlihat bahwa kontribusi terbesar yang mem-pengaruhi pertumbuhan ekonomi ber-sumber dari varians pertumbuhan dirinya sendiri. Kontirbusi tertinggi dalam jangka pendek sebesar 97,353\% pada periode ke 2 dan selanjutnya turun menjadi 39,148\% pada periode ke 36 . Kontribusi lainnya yang mem-pengaruhi pertumbuhan ekonomi berasal dari varians KATMDBT, KKRDT, NDBT, NEPAYMENT, NKLRG, NKRDT dan NRTGS.

Dalam jangka pendek yaitu periode ke 2, kontribusi varians KATMDBT sebesar 0,068\%, varians KKRDT sebesar 0,043\%, varians NDBT sebesar $0,042 \%$, varians NEPAYMENT sebesar $1,289 \%$, varians NKLRG sebesar $0,421 \%$, varians NKRDT sebesar $0,001 \%$ dan varians NRTGS sebesar $0,150 \%$. Sedangkan kontribusi variabel selain alat pembayaran nontunai yang digunakan dalam penelitian untuk varians BIRATE pada periode 2 sebesar $0,051 \%$, varians EXCRATE sebesar $0,518 \%$, serta varians INF sebesar $0,062 \%$. 
Sedangkan dalam periode jangka panjang yaitu pada periode ke 36, kontribusi varians masing-masing alat pembayaran nontunai mengalami peningkatan. Kon-tribusi varians KATMDBT meningkat men-jadi sebesar $25.043 \%$, varians KKRDT me-ningkat menjadi sebesar 4,540\%, varians NDBT meningkat menjadi sebesar $0,053 \%$, varians NEPAYMENT meningkat men-jadi sebesar 2,001\%, varians NKLRG me-ningkat menjadi sebesar 2,119\%, varians NKRDT meningkat menjadi sebesar $1,300 \%$ dan varians NRTGS meningkat menjadi sebesar 2,696\%. Untuk variabel selain alat pem-bayaran nontunai yang digunakan dalam penelitian, varians BIRATE mengalami pe-ningkatkan pada periode 36 menjadi 2,504\%, varians EXCRATE mengalami peningkatan menjadi $20,389 \%$, serta varians INF menurun menjadi $0,209 \%$.

Tabel 4

Variance Decomposition Of GDP Menggunakan Cek Dan Bilyet Giro

\begin{tabular}{|c|c|c|c|c|c|c|c|c|c|c|}
\hline $\begin{array}{c}\text { Perio } \\
\text { d }\end{array}$ & S.E. & GDP & $\begin{array}{c}\text { KATMD } \\
\text { BT }\end{array}$ & $\begin{array}{c}\text { KKRD } \\
\mathbf{T} \\
\end{array}$ & NCEK & $\begin{array}{c}\text { NDB } \\
\text { T }\end{array}$ & $\begin{array}{c}\text { NEPAYME } \\
\text { NT }\end{array}$ & $\begin{array}{c}\text { NGIR } \\
0\end{array}$ & $\begin{array}{c}\text { NKRD } \\
\text { T }\end{array}$ & $\begin{array}{c}\text { NRTG } \\
\text { S }\end{array}$ \\
\hline & & 100.00 & & & & & & & & \\
\hline 1 & 0.011 & 0 & 0.000 & 0.000 & 0.000 & 0.000 & 0.000 & 0.000 & 0.000 & 0.000 \\
\hline 2 & 0.016 & 91.526 & 0.401 & 0.014 & 1.540 & 0.043 & 0.879 & 1.100 & 0.023 & 0.011 \\
\hline 5 & 0.033 & 42.050 & 0.723 & 0.023 & 11.709 & 2.196 & 6.137 & 9.640 & 5.986 & 0.056 \\
\hline 6 & 0.039 & 36.208 & 0.938 & 0.052 & 12.549 & 2.526 & 7.330 & 10.051 & 7.239 & 0.057 \\
\hline 10 & 0.055 & 28.193 & 1.241 & 0.126 & 13.299 & 2.986 & 9.156 & 10.346 & 9.202 & 0.053 \\
\hline 15 & 0.070 & 25.272 & 1.333 & 0.152 & 13.603 & 3.145 & 9.792 & 10.444 & 9.905 & 0.052 \\
\hline 20 & 0.082 & 23.965 & 1.374 & 0.163 & 13.741 & 3.215 & 10.077 & 10.487 & 10.219 & 0.052 \\
\hline 25 & 0.093 & 23.224 & 1.397 & 0.169 & 13.819 & 3.255 & 10.238 & 10.512 & 10.397 & 0.051 \\
\hline 30 & 0.102 & 22.747 & 1.413 & 0.173 & 13.869 & 3.281 & 10.342 & 10.528 & 10.511 & 0.051 \\
\hline 35 & 0.111 & 22.415 & 1.423 & 0.176 & 13.904 & 3.299 & 10.415 & 10.539 & 10.591 & 0.051 \\
\hline 36 & 0.113 & 22.360 & 1.425 & 0.176 & 13.910 & 3.302 & 10.427 & 10.540 & 10.604 & 0.051 \\
\hline
\end{tabular}

Sumber : Data Olahan Eviews

Dalam tabel 4 yang merupakan hasil variance decomposition dari model yang memasukan variabel alat nontunai berupa cek dan bilyet giro, dari tabel tersebut terlihat bahwa bahwa kontribusi terbesar yang mempengaruhi pertumbuhan ekonomi bersumber dari varians pertumbuhan dirinya sendiri. Kontirbusi tertinggi dalam jangka pendek sebesar 91,526\% pada periode ke 2 dan selanjutnya turun menjadi $22.360 \%$ pada periode ke 36 . Kontribusi lainnya yang mempengaruhi pertumbuhan ekonomi berasal dari varians $K A T M D B T$, KKRDT, NCEK, NDBT, NEPAYMENT, NGIRO, NKRDT dan NRTGS.

Dalam jangka pendek yaitu periode ke 2, kontirbusi varians KATMDBT sebesar 0,401\%, varians KKRDT sebesar 0,014\%, varians NCEK sebesar $1,540 \%$, varians NDBT sebesar $0,043 \%$, varians NEPAYMENT sebesar $0,879 \%$, varians NGIRO sebesar $1,100 \%$, varians NKRDT sebesar $0,023 \%$ dan varians NRTGS sebesar $0,011 \%$. Sedangkan kontribusi variabel selain alat pembayaran nontunai yang digunakan dalam penelitian untuk varians BIRATE 
pada periode 2 sebesar 0,401\%, varians EXCRATE sebesar 2,065\%, serta varians INF sebesar $1,997 \%$.

Sedangkan dalam periode jangka panjang yaitu pada periode ke 36, kontribusi varians masing-masing alat pembayaran nontunai mengalami peningkatan. Kon-tribusi varians KATMDBT meningkat menjadi sebesar $1,425 \%$, varians KKRDT meningkat menjadi sebesar $0,176 \%$, varians NDBT meningkat menjadi sebesar $3.302 \%$, varians NCEK meningkat menjadi sebesar $13,910 \%$ varians NEPAYMENT meningkat menjadi sebesar $10.427 \%$, varians NGIRO meningkat menjadi sebesar $10,549 \%$, varians NKRDT meningkat menjadi sebesar $10,604 \%$ dan varians NRTGS meningkat menjadi sebesar $0,051 \%$. Untuk variabel selain alat pembayaran nontunai yang digunakan dalam penelitian, varians BIRATE mengalami peningkatkan pada periode 36 menjadi 0,155\%, varians EXCRATE me-ngalami peningkatan menjadi $19,785 \%$, serta varians INF meningkat menjadi 7,265\%.

\section{Analisis Pengaruh Peningkatan Pembayaran Nontunai Terhadap} Pertumbuhan Ekonomi Dalam Beberapa Periode Waktu

Untuk melihat dampak peningkatan pada alat pembayaran nontunai terhadap per-tumbuhan ekonomi, dilakukan pe-mecahan periode waktu penelitian. Hal tersebut dilakukan dengan tujuan dapat me-lihat prilaku dari masing-masing instrumen pembayaran nontunai yang digunakan dalam penelitian ini. Pemecahan periode estimasi dalam melihat prilaku ins-trumen pembayaran nontunai ini didasarkan atas peningkatan signifikan yang terjadi pada masing-masing instrumen pembayaran non-tunai yang digunakan.

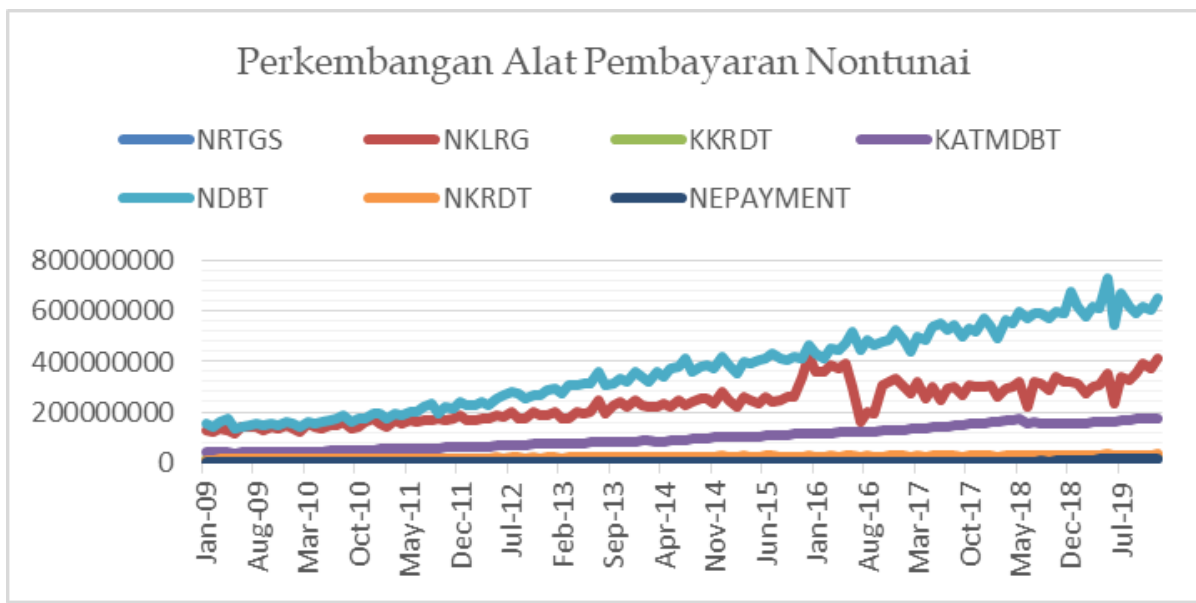

Grafik 1

Perkembangan alat pembayaran nontunai

Berdasarkan grafik 1 di atas, dapat terlihat bahwa memang alat pembayaran nontunai yang digunakan dalam penelitian memiliki tren yang positif dari waktu ke waktu. Dalam melihat prilaku data sepanjang periode penelitian pemecahan periode didasarkan pada peningkatan yang signifikan pada alat pem-bayaran nontunai yaitu periode sebelum dan sesudah 2015 . 
a) Estimasi VECM untuk periode 2009-2014

Berikut adalah hasil estimasi VECM untuk periode 2009-2014.

Tabel 5

Hubungan Antara Alat Pembayaran Nontunai Dengan Pertumbuhan Ekonomi 2009-2014

\begin{tabular}{|c|c|c|c|}
\hline Cointegrating Equation : & CointEq1 & CointEq2 & CointEq3 \\
\hline $\ln$ GDP(-1) & 1.000 & 0.000 & 0.000 \\
\hline $\ln$ EXCRATE(-1) & 0.000 & 1.000 & 0.000 \\
\hline BIRATE(-1) & 0.000 & 0.000 & 1.000 \\
\hline \multirow[t]{2}{*}{ INF(-1) } & -0.513 & -0.006 & -0.345 \\
\hline & {$[-6.77]^{* * *}$} & {$[-0.367]$} & {$[-4.119]^{* * *}$} \\
\hline \multirow[t]{2}{*}{$\ln$ KATMDBT(-1) } & 4.443 & 1.199 & 4.782 \\
\hline & {$[2.198]^{* *}$} & {$[2.749]^{* *}$} & {$[2.144]^{* *}$} \\
\hline \multirow[t]{2}{*}{$\operatorname{lnKKRDT(-1)}$} & -16.744 & 2.961 & 2.706 \\
\hline & {$[-5.777]^{* * *}$} & {$[4.733]^{* * *}$} & [0.846] \\
\hline \multirow[t]{2}{*}{$\ln \mathrm{NDBT}(-1)$} & -3.214 & 0.426 & -0.411 \\
\hline & {$[-3.348]^{* * *}$} & {$[2.056]^{* *}$} & {$[-0.388]$} \\
\hline \multirow[t]{2}{*}{$\ln$ NEPAYMENT(-1) } & -0.893 & -0.2169 & 0.447 \\
\hline & {$[-1.653]$} & {$[-1.860]^{*}$} & {$[0.750]$} \\
\hline \multirow[t]{2}{*}{$\ln$ NKLRG(-1) } & 1.997 & -1.461 & -16.083 \\
\hline & [ 0.894] & {$[-3.030] * * *$} & {$[-6.525]^{* * *}$} \\
\hline \multirow[t]{2}{*}{$\ln$ NKRDT(-1) } & 12.442 & -3.132 & 9.893 \\
\hline & {$[4.029]^{* * *}$} & {$[-4.699]^{* * *}$} & {$[2.903]^{* *}$} \\
\hline \multirow[t]{2}{*}{$\ln$ NRTGS(-1) } & -0.001 & -0.213 & 0.4371 \\
\hline & {$[-0.002]$} & {$[-2.137] * *$} & [0.859] \\
\hline
\end{tabular}

Sumber : Data Olahan Eviews,

*signifikan pada $\alpha=10 \%, * *$ signifikan pada $\alpha=5 \%$, *** signifikan pada $\alpha=1 \%$

Berdasarkan tabel 5. tersebut, maka per-samaan konitegrasi dari pada periode estimasi 2009-2014 diperoleh sebagai berikut:

$$
\begin{aligned}
& E C T_{t-1}=1.000 \ln G D P_{t-1}-0.513 I N F_{t-1}+4.443 \ln K A T M D B T_{t-1} \\
&-16.744 \ln K K R D T_{t-1}-3.214 \ln N D B T_{t-1} \\
&-0.893 \ln N E P A Y M E N T_{t-1}+1.997 \ln N K L R G_{t-1} \\
&-12.442 \ln N K R D T_{t-1}-0.001 \ln N R T G S_{t-1}
\end{aligned}
$$

Hasil estimasi VECM pada periode estimasi 2009-2014 menunjukkan nilai ECT yang signifikan secara statistik. Hal tersebut berimplikasi bahwa hasil estimasi VECM yang dilakukan adalah valid untuk dilakukan analisis. Hasil estimasi untuk nilai ECT (-1) yang diperoleh bernilai negatif dan kurang dari satu. Nilai ECT sebesar 0,018 bermakna jika terdapat perbedaan pada nilai aktual GDP dengan keseimbanganya sebesar 0,018, maka akan dikoreksi dan disesuaikan pada setiap periodenya.

Persamaan konitegrasi dan estimasi model jangka panjang yang ditunjukan pada tabel 5, terlihat bahwa adanya hubungan antara variabel 
nontunai yang digunakan dalam penelitian terhadap pertumbuhan ekonomi. Pada tabel tersebut juga dapat disimpulkan bahwa transaksi dengan alat pembayaran nontunai berupa volume dan nilai transkasi dari kartu kredit, volume dan nilai transaksi dari kartu kredit secara statistik signifikan dan berpengaruh pada pertumbuhan ekonomi. Pada periode 2009-2014, transk yang dilakukan masyarakat dengan menggunakan kartu kredit, setiap terjadi peningkatan $1 \%$ baik pada nilai maupun volume transaksi maka akan mempengaruhi pada peningkatan pertumbuhan ekonomi masing-masing sebesar $16.744 \%$ dan $3.132 \%$. Sedangkan transaksi yang dilakukan dengan menggunakan kartu debit, setiap terjadi kenaikan pada nilai ataupun volume transaksi yang dilakukan akan mempengaruhi pertumbuhan ekonomi masing-masing sebesar $3.214 \%$ dan $4.443 \%$.

b) Estimasi VECM untuk periode 2015-2019

Berikut adalah hasil estimasi VECM untuk periode 2015-2019.

Tabel 6

Persamaan Kointegrasi dan Model Jangka Panjang periode 2015-2019

\begin{tabular}{|c|c|c|c|}
\hline Cointegrating Equation : & CointEq1 & CointEq2 & CointEq3 \\
\hline $\ln$ GDP(-1) & 1.000 & 0.000 & 0.000 \\
\hline BIRATE(-1) & 0.000 & 1.000 & 0.000 \\
\hline lnEXCRATE(-1) & 0.000 & 0.000 & 1.000 \\
\hline \multirow{2}{*}{ INF(-1) } & 0.005 & -0.201 & 0.007 \\
\hline & {$[0.789]$} & {$[-0.843]$} & {$[0.346]$} \\
\hline \multirow[t]{2}{*}{$\ln$ KATMDBT(-1) } & 0.431 & 10.8811 & 0.312 \\
\hline & {$[3.471]^{* * *}$} & {$[2.118] * *$} & {$[0.777]$} \\
\hline \multirow[t]{2}{*}{$\ln$ KKRDT(-1) } & 0.353 & -37.810 & -2.505 \\
\hline & [1.477] & {$[-3.828] * * *$} & {$[-3.246]^{* * *}$} \\
\hline \multirow[t]{2}{*}{$\ln$ NDBT(-1) } & -2.088 & -16.545 & -1.429 \\
\hline & {$[-7.365]^{* * *}$} & {$[-1.411]$} & {$[-1.560]$} \\
\hline \multirow[t]{2}{*}{ lnNEPAYMENT(-1) } & 0.007 & -1.671 & -0.077 \\
\hline & {$[0.620]$} & {$[-3.808]^{* * *}$} & {$[-2.254]^{* *}$} \\
\hline \multirow[t]{2}{*}{$\ln$ NKLRG(-1) } & -0.086 & -0.986 & -0.003 \\
\hline & {$[-2.647]^{* *}$} & {$[-0.735]$} & {$[-0.030]$} \\
\hline \multirow[t]{2}{*}{$\ln$ NKRDT(-1) } & -0.476 & 20.724 & 1.103 \\
\hline & {$[-2.419] * *$} & {$[2.545]^{* *}$} & [1.733] \\
\hline \multirow[t]{2}{*}{$\ln$ NRTGS(-1) } & 0.959 & 23.236 & 1.955 \\
\hline & {$[9.081]^{* * *}$} & {$[5.318]^{* * *}$} & {$[5.727]^{* * *}$} \\
\hline
\end{tabular}

Sumber : Data Olahan Eviews,

*signifikan pada $\alpha=10 \%, * *$ signifikan pada $\alpha=5 \%$, *** signifikan pada $\alpha=1 \%$.

Berdasarkan tabel 6 tersebut, maka per-samaan konitegrasi dari pada periode estimasi 2015-2019 diperoleh sebagai berikut:

$$
\begin{aligned}
E C T_{t-1}=1.000 & \ln G D P_{t-1}+0.005 I N F_{t-1}+0.431 \ln K A T M D B T_{t-1} \\
& +0.353 \ln K K R D T_{t-1}-2.088 \ln N D B T_{t-1} \\
& +0.007 \ln N E P A Y M E N T_{t-1}-0.086 \ln N K L R G_{t-1} \\
& -0.476 \ln N K R D T_{t-1}-0.959 \ln N R T G S_{t-1}
\end{aligned}
$$


Pada periode estimasi 2015-2019, hasil estimasi VECM menunjukkan nilai ECT yang signifikan secara statistik pada model yang digunakan. Hal tersebut berimplikasi bahwa hasil estimasi VECM yang dilakukan adalah valid untuk dilakukan analisis. Dalam tabel 4.19, nilai koefisien atas ECT (1) bernilai negatif dan kurang dari satu. Nilai ECT sebesar 0,061 bermakna jika terdapat perbedaan pada nilai aktual GDP dengan keseimbanganya sebesar 0,061, maka akan dikoreksi dan disesuaikan pada setiap periodenya.

Pada tabel 6 yang menunjukkan hubungan jangka panjang untuk periode 2015-2019, ditunjukkan bahwa adanya hubungan dalam jangka panjang antara alat pembayaran nontunai dengan pertumbuhan ekonomi. Pada hasil tersebut dapat disimpulkan bahwa alat pembayaran nontunai berupa volume kartu ATM/Debit (KATMDBT), volume kartu kredit (KKRDT), nilai transaksi kartu debit (NDBT), nilai transaksi electronic money (NEPAYMENT), nilai transaksi kliring (NKLRG), nilai transaksi kartu kredit (NKRDT) dan nilai transaksi BI-RTGS (NRTGS) secara stastistik berpengaruh dan signifikan terhadap pertumbuhan ekonomi.

Pada periode 2015-2019, untuk setiap transaksi yang dilakukan dengan meng-gunakan kartu debit, setiap terjadi pe-ningkatan $1 \%$ baik pada nilai maupun vo-lume transaksi, maka akan berpengaruh pada pertumbuhan ekonomi masing-masing sebesar $2.088 \%$ dan $0.431 \%$ satuan GDP. Sedangkan transkasi yang dilakukan oleh masyarakat dengan menggunakan kartu kredit, setiap terjadi peningkatan $1 \%$ pada penggunaan kartu kredit baik untuk nilai maupun volume transaksi maka akan mempengaruhi pertumbuhan ekonomi masing-masing sebesar $0.476 \%$ dan $0.353 \%$ satuan GDP. Sedangkan untuk kegiatan transaksi yang dilakukan dengan menggunakan kliring, apabila terjadi peningkatan $1 \%$ pada transaksi kliring, akan berdampak pada peningkatan didalam pertumbuhan ekonomi sebesar $0.086 \%$ satuan GDP. Adapun transaksi yang dilakukan dengan menggunakan electornic money dan BI-RTGS, setiap terjadi peningkatan transaksi sebesar $1 \%$ maka akan berpengaruh pada peningkatan pertumbuhan ekonomi masing-masing $1.671 \%$ dan $0.959 \%$ satuan GDP.

\section{Analisis Variance Decomposition Alat Pembayaran Nontunai Terhadap Pertumbuhan Ekonomi Untuk Kedua Periode Estimasi}

Hasil variance decomposition alat pem-bayaran nontunai terhadap pertumbuhan ekonomi disajikan pada tabel berikut: 
Tabel 7

Hasil Variance Decomposition of GDP periode 2009-2014

\begin{tabular}{cccccccccc}
\hline $\begin{array}{c}\text { Period } \\
\mathbf{e}\end{array}$ & $\mathbf{S . E .}$ & $\mathbf{G D P}$ & $\begin{array}{c}\text { KATMDB } \\
\mathbf{T}\end{array}$ & $\begin{array}{c}\text { KKRD } \\
\mathbf{T}\end{array}$ & $\begin{array}{c}\text { NDB } \\
\mathbf{T}\end{array}$ & $\begin{array}{c}\text { NEPAYMEN } \\
\mathbf{T}\end{array}$ & $\begin{array}{c}\text { NKLR } \\
\mathbf{G}\end{array}$ & $\begin{array}{c}\text { NKRD } \\
\mathbf{T}\end{array}$ & $\begin{array}{c}\text { NRTG } \\
\mathbf{S}\end{array}$ \\
\hline $\mathbf{1}$ & 0,103 & 100,00 & 0,000 & 0,000 & 0,000 & 0,000 & 0,000 & 0,000 & 0,000 \\
& & 0 & & & & & & & \\
\hline $\mathbf{2}$ & 0,181 & 98,706 & 0,275 & 0,026 & 0,139 & 0,382 & 0,092 & 0,001 & 0,101 \\
\hline $\mathbf{5}$ & 0,366 & 96,464 & 0,168 & 0,117 & 0,503 & 0,447 & 0,258 & 0,009 & 0,199 \\
\hline $\mathbf{1 0}$ & 0,582 & 94,792 & 0,100 & 0,160 & 0,721 & 0,526 & 0,561 & 0,020 & 0,199 \\
\hline $\mathbf{1 5}$ & 0,743 & 93,985 & 0,074 & 0,185 & 0,793 & 0,576 & 0,747 & 0,033 & 0,210 \\
\hline $\mathbf{2 0}$ & 0,876 & 93,537 & 0,061 & 0,199 & 0,827 & 0,606 & 0,854 & 0,042 & 0,218 \\
\hline $\mathbf{2 5}$ & 0,992 & 93,265 & 0,053 & 0,207 & 0,847 & 0,625 & 0,919 & 0,048 & 0,223 \\
\hline $\mathbf{3 0}$ & 1,095 & 93,086 & 0,048 & 0,213 & 0,860 & 0,637 & 0,963 & 0,052 & 0,226 \\
\hline $\mathbf{3 5}$ & 1,190 & 92,961 & 0,045 & 0,217 & 0,869 & 0,646 & 0,993 & 0,055 & 0,229 \\
\hline $\mathbf{3 6}$ & 1,208 & 92,940 & 0,044 & 0,217 & 0,871 & 0,647 & 0,998 & 0,055 & 0,229 \\
\hline
\end{tabular}

\section{Sumber : Data Olahan Eviews}

Dalam tabel 7 yang merupakan hasil variance decomposition untuk periode 2009-2014 terlihat bahwa kontribusi terbesar yang mempengaruhi pertumbuhan ekonomi bersumber dari varians pertumbuhan dirinya sendiri. Kontirbusi tertinggi dalam jangka pendek sebesar $98,706 \%$ pada periode ke 2 dan selanjutnya turun menjadi $92,940 \%$ pada periode ke 36 . Kontribusi lainnya yang mempengaruhi pertumbuhan ekonomi berasal dari varians $K A T M D B T, K K R D T$, NDBT, NEPAYMENT, NKLRG, NKRDT dan NRTGS.

Dalam jangka pendek yaitu periode ke 2, kontirbusi varians KATMDBT sebesar 0,275\%, varians KKRDT sebesar 0,026\%, varians NDBT sebesar $0,139 \%$, varians NEPAYMENT sebesar $0,392 \%$, varians NKLRG sebesar $0,092 \%$, varians NKRDT sebesar $0,001 \%$ dan varians NRTGS sebesar $0,101 \%$. Sedangkan kontribusi variabel selain alat pembayaran nontunai yang digunakan dalam penelitian untuk varians BIRATE pada periode 2 sebesar $0,001 \%$, varians EXCRATE sebesar 0,119\%, serta varians INF sebesar 0,159\%.

Sedangkan dalam periode jangka panjang yaitu pada periode ke 36, kontribusi varians masing-masing alat pembayaran nontunai mengalami peningkatan. Kon-tribusi varians KATMDBT meningkat menjadi sebesar 0,044\%, varians KKRDT me-ningkat menjadi sebesar 0,217\%, varians NDBT meningkat menjadi sebesar $0,871 \%$, varians NEPAYMENT meningkat menjadi sebesar 0,647\%, varians NKLRG meningkat menjadi sebesar 0,998\%, varians NKRDT meningkat menjadi sebesar $0,055 \%$ dan varians NRTGS meningkat menjadi sebesar $0,229 \%$. Untuk variabel selain alat pembayaran nontunai yang digunakan dalam penelitian, varians BIRATE mengalami peningkatkan pada periode 36 menjadi $0,044 \%$, varians EXCRATE pada periode 36 mengalami peningkatan menjadi $3,880 \%$, serta varians INF menurun menjadi $0,074 \%$ pada periode ke 36. 
Tabel 8

Hasil Variance Decomposition of GDP periode 2015-2019

\begin{tabular}{cccccccccc}
\hline $\begin{array}{c}\text { Period } \\
\text { e }\end{array}$ & S.E. & GDP & $\begin{array}{r}\text { KATMDB } \\
\text { T }\end{array}$ & $\begin{array}{r}\text { KKRD } \\
\mathbf{T}\end{array}$ & $\begin{array}{r}\text { NDB } \\
\mathbf{T}\end{array}$ & $\begin{array}{r}\text { NEPAYMEN } \\
\mathbf{T}\end{array}$ & $\begin{array}{r}\text { NKLR } \\
\mathbf{G}\end{array}$ & $\begin{array}{r}\text { NKRD } \\
\mathbf{T}\end{array}$ & $\begin{array}{r}\text { NRTG } \\
\mathbf{S}\end{array}$ \\
\hline $\mathbf{1}$ & 0,007 & 0 & 0,000 & 0,000 & 0,000 & 0,000 & 0,000 & 0,000 & 0,000 \\
\hline $\mathbf{2}$ & 0,015 & 92,379 & 0,000 & 0,178 & 0,366 & 2,509 & 0,048 & 0,120 & 2,173 \\
\hline $\mathbf{5}$ & 0,040 & 74,899 & 0,960 & 0,416 & 3,175 & 7,056 & 0,024 & 1,308 & 3,491 \\
\hline $\mathbf{1 0}$ & 0,072 & 64,017 & 3,602 & 0,360 & 4,899 & 11,914 & 0,025 & 3,330 & 2,102 \\
\hline $\mathbf{1 5}$ & 0,097 & 59,800 & 5,096 & 0,273 & 5,308 & 13,979 & 0,085 & 4,473 & 1,584 \\
\hline $\mathbf{2 0}$ & 0,118 & 57,691 & 5,909 & 0,227 & 5,462 & 14,998 & 0,139 & 5,095 & 1,339 \\
\hline $\mathbf{2 5}$ & 0,135 & 56,492 & 6,383 & 0,201 & 5,539 & 15,571 & 0,174 & 5,458 & 1,203 \\
\hline $\mathbf{3 0}$ & 0,151 & 55,737 & 6,683 & 0,185 & 5,585 & 15,930 & 0,198 & 5,688 & 1,118 \\
\hline $\mathbf{3 5}$ & 0,165 & 55,224 & 6,888 & 0,173 & 5,616 & 16,174 & 0,215 & 5,846 & 1,060 \\
\hline $\mathbf{3 6}$ & 0,168 & 55,141 & 6,921 & 0,172 & 5,621 & 16,213 & 0,218 & 5,871 & 1,051 \\
\hline
\end{tabular}

Pada tabel 8 yang merupakan hasil variance decomposition untuk periode 2015-2019 terlihat bahwa kontribusi terbesar yang mempengaruhi pertumbuhan ekonomi bersumber dari varians pertumbuhan dirinya sendiri. Kontirbusi tertinggi dalam jangka pendek sebesar 92,379\% pada periode ke 2 dan selanjutnya turun menjadi $55,141 \%$ pada periode ke 36 . Kontribusi lainnya yang mempengaruhi pertumbuhan ekonomi berasal dari varians $K A T M D B T, K K R D T$, NDBT, NEPAYMENT, NKLRG, NKRDT dan NRTGS.

Dalam jangka pendek yaitu periode ke 2, varians KATMDBT belum berkontribusi $(0,000 \%)$ terhadap pertumbuhan ekonomi, sedangkan kontribusi varians KKRDT sebesar 0,178\%, varians NDBT sebesar 0,366\%, varians NEPAYMENT sebesar 2,509\%, varians NKLRG sebesar 0,048\%, varians NKRDT sebesar 0,120\% dan varians NRTGS sebesar 2,173\%. Sedangkan kontribusi variabel selain alat pembayaran non-tunai yang digunakan dalam penelitian untuk kontribusi varians BIRATE pada periode 2 sebesar 0,777\%, varians EXCRATE sebesar 0,321\%, serta varians INF pada sebesar 1,130\%.

Sedangkan dalam periode jangka panjang yaitu pada periode ke 36, kontribusi varians KATMDBT meningkat menjadi sebesar 6,921\%, varians KKRDT turun menjadi sebesar $0,172 \%$, varians NDBT me-ningkat menjadi sebesar 5,621\%, varians NEPAYMENT meningkat menjadi sebesar 16,213\%, varians NKLRG meningkat menjadi sebesar 0,218\%, varians NKRDT meningkat menjadi sebesar 5,871\% dan varians NRTGS turun menjadi sebesar $1,051 \%$. Untuk variabel selain alat pembayaran non-tunai yang digunakan dalam penelitian, kon-tribusi varians BIRATE mengalami peningkatkan pada periode 36 menjadi 2,239\%, varians EXCRATE mengalami pe-ningkatan menjadi $1,331 \%$, serta varians INF meningkat menjadi 5,222\%.

Dampak positif dari penggunaan alat pembayaran nontunai khususnya alat pembayaran nontunai berupa kartu menyebabkan terjadinya peningkatan dalam pertumbuhan ekonomi. Hal tersebut sangat erat kaitanya dengan manfaat yang 
diterima atas peng-gunaan alat pembayaran nontunai tersebut yaitu berupa kemudahan dan keamanan yang diperoleh dalam melakukan transaksi tanpa menggunakan uang tunai. Dari aspek keamanan juga lebih terjamin dikarenakan individu tidak perlu membawa uang tunai, sehingga risiko atas terjadinya kehilangan atau kecopetan juga semakin kecil. Peng-gunaan alat pembayaran nontunai juga me-ningkatkan efisinsi dan efektivitas bagi ma-syarakat serta bagi sistem keuangan secara keseluruhan. Sehingga dengan begitu akan mendorong terjadinya peningkatan kon-sumsi bagi masyarakat. Akibatnya dengan adanya peningkatan konsumsi tersebut dapat meningkatkan pertumbuhan ekonomi.

Selain berdampak pada peningkatkan konsumsi, alat pembayaran nontunai juga dapat berpengaruh atas terjadinya pe-nurunan dalam permintaan uang dimasyarakat. Terjadinya penurunan per-mintaan uang yang dilakukan oleh masyarakat dapat memicu terjadinya pe-nurunan suku bunga dipasar uang. Hal itu disebabkan karena masyarakat akan lebih menggunakan alat pembayaran nontunai yang dapat digunakan langsung untuk ber-transaksi sekaligus juga untuk menyimpan uang yang dimilikinya. Sehingga membuat biaya pinjaman menjadi lebih kompetitif, akibatnya akan memicu terjadinya pe-ningkatan dalam investasi dan pada gilirannya akan meningkatkan output rill nasional dan terjadinya pertumbuhan ekonomi serta meningkatnya kesejahteraan masyarakat.

Hubungan positif di antara sistem pembayaran nontunai dengan GDP sebagai indikator perekonomian yang digunakan dalam penelitian ini sejalan dengan penelitian yang dilakukan oleh (Pramono et al., 2006), dalam hasil penelitian yang dilakukan olehnya dijelaskan bahwa munculnya berbagai alat pembayaran non-tunai pada perekonomian akan memberikan manfaat berupa peningkatan efisiensi serta produktivitas dalam keuangan, sehingga dengan begitu nantinya akan meningkatkan aktivitas pada sektor rill. Peningkatan aktivitas yang terjadi pada sektor rill oleh pramono disebutkan dalam penilitiannya bahwa pada gilirannya akan berpotensi mendorong terjadinya pertumbuhan ekonomi dan tingkat kesejahteraan pada ma-syarakat. Hasil penelitian ini juga sejalan dengan penelitian yang telah dilakukan oleh (Syarifuddin et al., 2009) yang menyatakan bahwa adanya kenaikan pada penggunaan alat pembayaran nontunai juga akan me-motong biaya transaksi dan membuat kondisi ekonomi akan menjadi efisien. Kenaikan alat pembayaran nontunai juga menurutnya akan menstimulus terjadinya pertumbuahn GDP dan menurunkan tingkat harga.

Berdasarkan (Moelgini et al., 2019), dengan proksi kartu ATM/Debet sebagai alat pembayaran nontunainya, dalam hasil penelitiannya dinyatakan bahwa kartu ATM/Debit tersebut berpengaruh terhadap pertumbuhan ekonomi. Serta dalam (Zandi et al., 2013) dengan melakukan penelitian pada 56 negara dalam periode waktu 5 tahun, didalam hasil penelitiannya disebutkan bahwa elctronic payment akan memberikan kontribusi pada GDP baik pada emerging 
market maupun developed market. Serta adanya pertumbuhan GDP selanjutnya akan menciptkan lapangan pekerjaan baru bagi masyarakat.

Tidak berpengaruhnya alat pembayaran nontunai terhadap GDP dalam jangka pendek didukung oleh penelitian yang dilakukan oleh (Tee \& Ong, 2016) mengenai Cashless Payment and Economic Growth yang dimana dikatakan pada hasil penelitiannya bahwa memang dalam jangka pendek penerapan salah satu tipe pembayaran nontunai akan memiliki efek pada tipe pembayaran lainnya. Namun dampak pembayaran nontunai tersebut dalam perekonomian akan berpengaruh secara signifikan dan baru akan dirasakan dampaknya dalam jangka panjang, tidak dirasakan secara langsung.

\section{Kesimpulan}

Berdasarkan hasil penelitian yang telah dilakukan mengenai peningkatan pembayaran nontunai dalam mempengaruhi perekonomian, dapat disimpulkan bahwa secara umum peningkatan pembayaran non-tunai dapat mempengaruhi perekonomian dengan pendekatan GDP untuk periode 2009 hingga 2019. Adapun bentuk pengaruh peningkatan pembayaran nontunai terhadap perekonomian adalah sebagai berikut: Hasil estimasi pengaruh pembayaran nontunai terhadap perekonomian dengan pendekatan GDP yaitu sebagai berikut:

Alat pembayaran nontunai dengan alat pembayaran menggunakan kartu dengan proksi nilai dan volume transkasi dari kartu ATM/debit berpengaruh positif dan signifikan dalam jangka panjang maupun jangka pendek terhadap GDP. Pendekatan alat pem-bayaran nontunai lain berupa kartu kredit dengan proksi data nilai volume transaksi dari kartu kredit miiliki hubungan positif dan signifikan dalam jangka panjang maupun jangka pendek dalam mempengaruhi GDP.

Alat pembayaran nontunai berupa BI-RTGS memiliki hubungan positif dan signifikan dalam mempengaruhi GDP dalam jangka panjang namun tidak untuk jangka pendek. Sedangkan alat pembayaran nontunai yang berbasis kertas berupa cek memiliki hubungan negatif dan tidak signifikan dalam mem-pengaruhi GDP. Sedangkan giro yang juga merupakan alat pembayaran non-tunai berbasis kertas berpengaruh secara signifikan dan memiliki hubungan positif dalam jangka panjang dalam mempengaruhi GDP, namun tidak dalam jangka pendek. Untuk alat pem-bayaran nontunai berupa elektronic money, memiliki hubungan yang positif dan signifikan terhadap GDP. 


\section{BIBLIOGRAFI}

Aristiyowati, E. S., \& Falianty, T. A. (2019). Peranan Perkembangan Inovasi Finansial Sistem Pembayaran Dalam Mempengaruhi Permintaan Uang Di Indonesia. EKUITAS (Jurnal Ekonomi Dan Keuangan), 2(3), 404. https://doi.org/10.24034/j25485024.y2018.v2.i3.128 Google Scholar

Bank Indonesia. (2011). Sistem Pembayaran di Indonesia. Google Scholar

Cassoni, A., \& Ramada, C. (2013). Digital Money and its Impact on Local Economic Variables: The Case of Uruguay. Universidad ORT Uruguay, 1-37. Google Scholar

Dias, J. (2001). Digital Money: Review of Literature and Simulation of Welfare Improvement of This Technological Advance. Department of Economics State University of Maringa, Brazil. Google Scholar

Hidayat, A., Firmansyah, A., Aulia, F., \& Dkk. (2006). Upaya Meningkatkan Penggunaan Alat Pembayaran Non Tunai Melalui Pengembangan E-Money. Working Paper Bank Indonesia, 48. Google Scholar

Igamo, A. M., \& Falianty, T. A. (2018). The Impact of Electronic Money on The Efficiency of The Payment System and The Substitution of Cash in Indonesia. Journal SIJDEB, 2(3), Hal : 237-254. Google Scholar

Lucas, R. E. (1995). The Monetary Neutrality. The Nobel Lectures, 1970. Google Scholar

Moelgini, Y., Nursari, A., \& Suparta, I. W. (2019). Pengaruh Pembayaran Non Tunai Terhadap Jumlah Uang Yang Diminta Masyarakat (M1) Dan Perekonomian Oleh: Jurnal Ekonomi Pembangunan, 8, 285-306. Google Scholar

Mulyati, S. T. S., \& Ascarya. (2003). Kebijakan Sistem Pembayaran di Indonesia. In Pusat Pendidikan dan Studi Kebansentrakan (PPSK) Bank Indonesia (Seri Keban, Issue 8). Pusat Pendidikan dan Studi Kebanksentralan (PPSL) BI. Google Scholar

Nirmala, T., \& Widodo, T. (2011). Effect of Increasing Use the Card Payment Equipment on the Indonesian Economy. Jurnal Bisnis Dan Ekonomi, 18(1), Hal : 36-45. Google Scholar

Oyewole, O. S., El-Maude, Gambo, J., Abba, M., \& Onuh, M. E. (2013). Electronic Payment System and Economic Growth: A Review of Transition to Cashless Economy in Nigeria. International Journal of Scientific Engineering and Technology, 2(9), 913-918. Google Scholar

Pramono, B., Yanuarti, T., \& Purusitawati, P. D. (2006). Dampak Pembayaran Non Tunai Terhadap Perekonomian dan Kebijakan Moneter. Bank Indonesia. Google Scholar 
Syarifuddin, F., Hidayat, A., \& Tarsidin. (2009). Dampak Peningkatan Pembayaran Non-Tunai terhadap Perekonomian dan Implikasinya terhadap Pengendalian Moneter di Indonesia. Buletin Ekonomi Moneter Dan Perbankan, 369-402. Google Scholar

Tee, H. H., \& Ong, H. B. (2016). Cashless payment and economic growth. Financial Innovation, 2(1), 1-9. https://doi.org/10.1186/s40854-016-0023-z Google Scholar

Warjiyo, P., \& Solikin. (2003). Alat Kebijakan Moneter Di Indonesia. In Pusat Pendidikan dan Studi Kebansentrakan (PPSK) Bank Indonesia (Vol. 3, Issue 1). https://doi.org/10.28932/jmm.v3i1.112 Google Scholar

Warjiyo, P., \& Solikin, M. J. (2016). Kebijakan Bank Sentral : Teori dan Praktik. PT. Raja Grafindo Persada. Google Scholar

Zandi, M., Singh, V., \& Irving, J. (2013). The impact of electronic payments on economic growth. Moody's Analytics, February. Google Scholar

\section{Copyright holder:}

Abdul Azis, Mahyus Ekananda (2021)

First publication right:

Syntax Literate: Jurnal Ilmiah Indonesia

This article is licensed under:

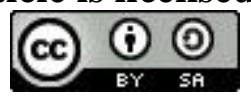

